\title{
Against a Melancholic Art History
}

\author{
The Afterlife of Images
}

\author{
Chari Larsson
}

The temporal distance between images and words we use to describe them, has led Michael Ann Holly to identify art history as a quintessentially melancholic discipline. Severed from its historical origins, something in the image remains elusive, evades our grasp and refuses to be tamed by language. As is well known, Sigmund Freud defined two possible and opposing responses to loss-mourning and melancholia. Mourning is considered a normative part of the grieving process. Melancholia, however, is pathological. The subject's ego identifies with the lost loved object, eventually incorporating the object. Building on Freud's thesis, Holly has argued that melancholy might be understood as a productive mode of historiography. This chapter will proceed in two sections. The first will examine Holly's exegesis of Freud's theorization of melancholia, maintaining Holly does not truly yield to Freud's melancholic ego and its obsessions. Instead, melancholia is deployed creatively, drawing on Renaissance and Romantic notions of creativity and genius. The second section will propose an anti-melancholic reading of the discipline that does not dwell on the object's absence. Drawing on French art historian Georges Didi-Huberman's arguments concerning anachronism, close attention will be paid to Pascal Convert's series of wax sculptures. This chapter will argue that what is at stake here is precisely the opposite of melancholy: the joyful affirmation of the return.

In her recent book The Melancholy Art, Michael Ann Holly has proposed that melancholy might serve as a central trope for the discipline of art history. Art history's historicism engenders a deep sense of melancholy in the art historian. With the exception of contemporary art, the temporal distance between the art historian and the image cannot be successfully traversed. We will never properly "know" the image, or accurately recreate the historical and cultural conditions under which it was produced, or understand the ambitions of the artist who created it. Art historical investigations are propelled by this sense of lost origin. The tension between the art historian's urge to recover and restore meaning and the ultimate futility of this activity might be formulated as a form of melancholy. Longing for an absent origin drives the grieving process. This melancholic desire for an absent past may be framed in Platonic-idealistic terms of deficiency and lack.

Writing further distorts the distance between the present and the past by inserting an additional layer between the image and its beholder. For Holly, the act of art writing paradoxically enacts this inevitable loss. Words ultimately fail the image. Nevertheless, our duty of care is great, as it is our task to keep the image alive against history itself. As Holly puts it: "the distance between present and past, the gap between words and images can never be closed." If the image ultimately remains resistant to 
writing, Holly's rhetorical style enacts this sense of loss. Her tone eloquently captures an enduring sense of melancholy. Grief gains hold on the reader as sadness emanates from the hauntingly sorrowful text. Implicit in her argument is how precarious our grasp on memory and the truth of the art object is. The present is unable to truly recreate the past and the past remains a lost and absent object. Disciplinary activities are directed by this enduring state of melancholic yearning. Holly states, "We preserve, study, exhibit, and write about the representational past because we cannot let it go."

Holly points to Sigmund Freud's theorization of melancholy as providing a framework for thinking through the relationship between the image and the art historian. In his 1917 essay "Mourning and Melancholia," Freud described two different types of grief. According to Freud, mourning is a healthy, natural response to loss. The lost object is eventually relinquished by the mourner. Mourning is a necessary part of the grieving process where the subject's ego has a strong attachment to the lost object. The ego is temporarily detained from its usual activities. Nevertheless, despite identification with the lost object, the ego progressively separates in a graduated process, eventually returning to normal and becoming free and uninhibited once again. Mourning is finite, with a distinct beginning and end.

Against the normative processes of mourning, Freud proposes that melancholy is a pathological deviation. Like the mourner, the melancholic's ego identifi es with the lost object. Unlike the temporarily restricted process of mourning, however, the melancholic languishes. The relationship between the ego and the object is intensified: there is a slippage, and the lost object is absorbed into the ego itself. Or, to put it another way, the ego is unable to freely reengage in its activities, eventually becoming the origin or source of melancholy. The origin of melancholia is displaced from the lost love-object to the subject's ego. It behaves, as Freud describes it, "like an open wound." ${ }^{3}$ The ego's absorption of itself is kept alive and the wound is unable to heal. As Freud makes clear, melancholy is produced via a narcissistic process of identification with the originary object. This identifi cation is framed in representational terms as a likeness or sameness: the ego identifi es with the object to the point that it is actually absorbed into the ego itself. Freud writes, "the love for the object-a love which cannot be given up though the object itself is given up." ${ }^{4}$ The melancholic ego seeks to restore presence by means of imitation, resemblance, and recognition.

Holly reiterates Freud's metaphor of the open wound, writing "A historiographer does not have to scratch the surface very deeply to recognize that the wound caused by the separation of time and distance will always continue to bleed." Holly's point is that the art historian's obsession might be discerned as a form of melancholic languishing, with the ego's inability to detach from the image. The melancholic ego becomes fi xed or stuck as it deteriorates, unable to reconcile the lost object and move "forward" like the mourner. Freud explains, "In mourning it is the world which has become poor and empty; in melancholia it is the ego itself." ${ }^{6}$ Writing, despite its promises, will never truly inoculate the art historian against a profound and enduring sense of melancholy. Words cannot heal the wound, as the image remains stubbornly resistant to treatment.

For Freud, the melancholic subject's narcissistic identifi cation with the lost object turns to sadism and hatred, stating "the hate comes into operation on this substitutive object, abusing it, debasing it, making it suffer and deriving sadistic satisfaction from

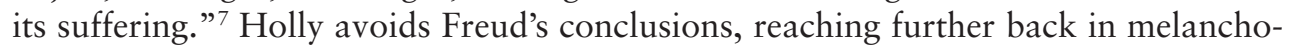
lia's long history, gently directing the melancholic yearning in the direction of Italian 
humanism and the Renaissance as a fertile source of creative energy. ${ }^{8}$ This particular strain of melancholy is embraced by Holly as a creative mode for disciplinary activity, neatly sidestepping the trauma endured by Freud's melancholic subject.

As a theory of unresolved grief, melancholy's imitative narcissism is a useful departure point for thinking through origins that are not based on resemblance. Perhaps, there is another way to think through the absent origin. In his 1967 essay "Structure, Sign, and Play," Jacques Derrida famously identifi ed two possible responses to the loss of origin. Derrida contrasted Rousseau's melancholic "sad, negative, nostalgic, guilty" with a Nietzschean avowal of, "the joyous affirmation of the freeplay of the world and without truth, without origin." Building on Derrida's observations, art historians are increasingly seeking to reclaim a lost or absent origin productively, by embracing anachronism as a strategy for reconfiguring linear history. ${ }^{10}$ If anachronism is defi ned as the intrusion of one historical era into another, art history has traditionally sought to preserve an appropriate gap from the art object to ensure the art historian's contemporaneity is kept separate and distinct. ${ }^{11}$ Erwin Panofsky memorably advised "To grasp reality, we have to detach ourselves from the present." 12 Panofsky's caution refl ects a self-conscious historicity whereby the discipline is carefully committed to maintaining distance between itself and the artwork. Appropriate historical distance ensured that the threat of anachronism was minimized, a built-in safeguard maintaining the art historian's objectivity. Against this, Holly acknowledges the temporal paradox contained by the image:

The materiality, the very physicality, of the works of art which we deal is a challenge to ever seeing the past as over and gone. They exist in the same space as their analysts, yet their sense of time is hardly congruent with ours. ${ }^{13}$

The image's materiality quietly asserts itself in our own contemporaneity, complicating traditional notions of origins and historical distance.

French art historian Georges Didi-Huberman has placed anachronism at the centre of his project. One of Didi-Huberman's key theoretical concerns is to elucidate a model of temporality that disrupts traditional understandings of origins and linear temporality. To do this, he constructs a theoretical nexus incorporating Aby Warburg, Friedrich Nietzsche and Gilles Deleuze that is antithetical to Freud's theorization of melancholic imitation of a lost or absent origin. Anachronism is appropriated here no longer as a taboo, but rather a dynamic and positive mode for imagining the artwork as the site of a plurality of possible temporalities. Didi-Huberman's commitment to anachronism reflects a broader shift in contemporary intellectual thought in France that has sought to rescue anachronism from its historically negative and pejorative conations. ${ }^{14}$ No longer the "black beast" ${ }^{15}$ of history, anachronism becomes a necessary condition in the understanding of images.

One of the most important figures in Didi-Huberman's theorization of anachronism is German art historian Aby Warburg, the most melancholic of art historians. Writing in the earliest decades of the twentieth century, Warburg was interested in tracing what he described as "a psychological history of expression" from antiquity through to his own contemporaneity. ${ }^{16}$ Seeking to undertake a revision of the existing models of disciplinary temporality that he had inherited from his predecessors, Warburg developed an alternative model of time based on two interconnected notions. The 
first Nachleben, literally Nach or after and leben, life. The second was Pathosformel, or pathos gestures. Warburg argued certain emotional gestures migrate and reappear, after long periods of dormancy, invested with a heightened degree of increased intensity. The terms were introduced in a short text of 1905, "Dürer and the Italian Antiquity," where Warburg analyzed the uncanny similarity of gestures between Albrecht Dürer's Death of Orpheus and fi gures depicted on ancient Greek vases. Orpheus is shown kneeling with his hand raised in a defensive gesture, protecting his head from an anticipated oncoming blow. Warburg concludes that the "psychology of style" is the product of the "long migration that brought antique superlatives of gesture from Athens, by way of Rome, Mantua, and Florence, to Nuremberg and into the mind of Albrecht Dürer." ${ }^{17}$ Warburg's terms point to a reimagining of history that is closer to Nietzsche than Hegel, leading Didi-Huberman to advance the thesis that the time of the image is not the time of history. ${ }^{18}$

Didi-Huberman identifi es a ghost-like model of temporality in Nachleben that puts traditional notions of origin under pressure. Didi-Huberman writes, "In Warburg's work, the term Nachleben refers to the survival (the continuity or afterlife and metamorphosis) of images and motifs-as opposed to their renascence after extinction." ${ }^{19}$ What is at stake here is a mode of temporality that is not chronological. To do this, Didi-Huberman builds a bridge from Warburg to Deleuze via Nietzsche. For Didi-Huberman, the resurgence or reappearance of gestures cannot be recognized in traditional art historical terms as a straightforward imitation: in the repetition of the gesture, something new is created. In Nachleben Didi-Huberman detects the most proto-Deleuzian impulse in Warburg's writing. In other words, we might provocatively assert that in Didi-Huberman's hands, Warburg looks forward in history, anachronistically anticipating Deleuze's theorization of difference.

Difference and repetition are key operative terms in Deleuze's vocabulary. The first point to recognize is Deleuze does not approach the terms as they have traditionally been understood. The question Deleuze asks throughout his text Difference and Repetition: what makes difference possible? How can difference be formulated other than subordination to the same? If difference has typically been defi ned as difference to and from the same, it has therefore been subordinated to identity, recognition, analogy, and imitation. How, then, can difference be imagined not as the other to or opposed to? The concept of repetition is important to unlocking Deleuze's reformulation of difference. Repetition for Deleuze does not equate to equivalence or sameness. Instead, repetition is best appreciated in terms of the production of something new. Repetition therefore is not produced through identity and recognition, but Deleuze's formulation of difference. This is the rend Deleuze strikes against traditional understandings of representation. Repetition does not seek to emulate original Platonic forms, or engage in the endless production of copies. No longer imitative, repetition becomes generative.

The notion of repetition as generative and affi rmative is drawn from Deleuze's reading of Nietzsche's doctrine of eternal return with its emphasis on movement, change, and alteration. As Deleuze observes in Nietzsche and Philosophy, the eternal return for Nietzsche was not linked to the repetition of the same, but on the contrary, marked a slippage or even a mutation. In other words, the eternal return is the recurrence of difference, of difference in itself. Once repetition is freed from the strictures of imitation, it becomes productive, becoming an "object of affi rmation and enjoyment." 20 Most importantly, for Deleuze, this is constructed in positive terms, as Nietzsche 
demonstrates that "difference is happy; that multiplicity, becoming and chance are adequate objects of joy by themselves and that only joy returns." 21

Accentuating Warburg's proximity to Nietzsche, the migration of motifs from antiquity is not considered by Didi-Huberman in imitative terms:

This is exactly what Warburg had sought in the expression of an eternal return of antique resemblances-an eternal return which was thinkable beyond any trivial relations, beyond all models of time which the idea of an imitation of antique models generally postulates.

Voilà exactement ce que Warburg a recherché dans l'expression d'un éternel retour des ressemblances antiques-un éternel retour qui fût pensable par-delà toute relation triviale, par-delà tout modèle de temps que suppose en général l'idée d'une imitation des modèles antiques. ${ }^{22}$

As Didi-Huberman emphasizes, the resurgence or reappearance of Pathosformel is something more than a straightforward imitation: in the repetition of the gesture, something new is created.

Returning to Freud, Deleuzian difference is incompatible with Freud's melancholic ego based on identification and absorption. To recast in Deleuzian terms, Freud proposes a model of resemblance predicated on equivalence. Deleuze develops a concept of difference not defined by sameness, or its relation to something else. Instead, for Deleuze, difference repeats itself, but this does not mean evoking the same or the identical. Alternatively, repetition is productive and affirmative. As such, difference is understood not in oppositional or negative terms, but rather in respect to multiplicity and diversity. This is Deleuze's "Copernican Revolution" that opens up the possibility of difference having its own concept, freed from the strictures of representation, identity and the same.

To understand how Warburg's model of ghost-like temporality might work in a contemporary context, let's turn now to French artist, Pascal Convert, who in 1999 began constructing a series of three monumental sculptures in wax for the Mudam Luxembourg (Plates 15 and 16, Figure 11.1) The sculptures are walls of wax, looming over the spectator. Slightly concave, the sculpture does not project outwards like a relief into the spectator's space. Instead, it has been cast or imprinted in the negative, retreating into its own space. Like an ancient frieze, the works command the spectator's frontality. To make sense of and decipher the strange recessions and pools of light, the spectator must stand directly in front. Convert's choice of medium similarly undermines expectations. The opaque solidity of the sculpture is evocative of marble. On closer inspection, it is made from wax. Slowly, the work begins to reveal itself and the spectator is gradually presented with a series of life-size figures. The figures form hollows and absences in the wall, negative forms that retreat rather than advance. Spanning the wall are voids or holes, allowing light from behind to shine through the wall of wax. The holes are in fact the figures' hands, cast in copper and starkly contrasting against the opaque ivory of the wax. The holes undermine the solidity of the wall, reminding the spectator that wax is in fact fragile, easily manipulated and labile. Like a succession of vanishing points, the copper voids organizes the spectator's gaze, directing it towards a sequence of absences. The warm luminosity of the reddish-brown copper returns light and movement back to the spectator. This is in stark juxtaposition to the milky wax, which in comparison, imbibes the surrounding light. 


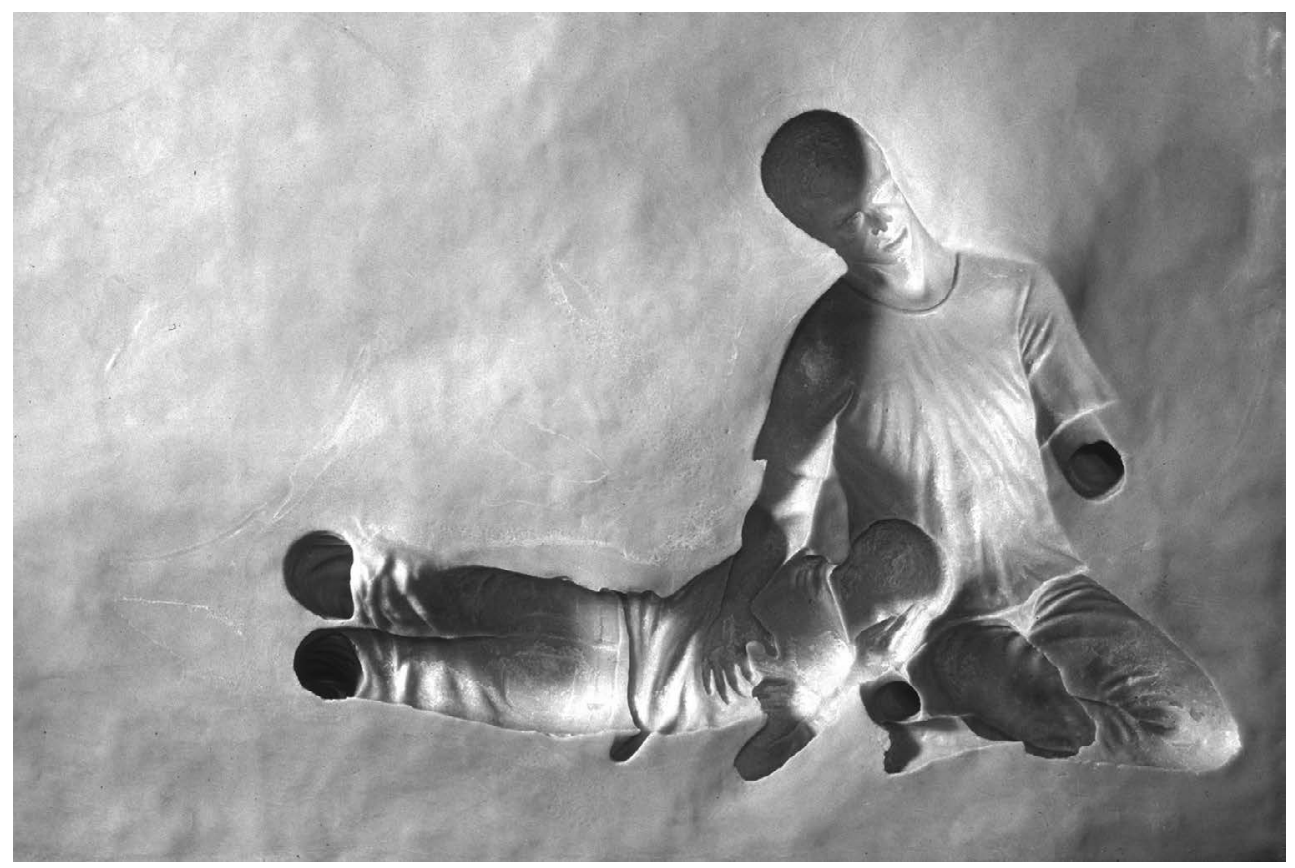

Figure 11.1 Pascal Convert, Mohamed Al Dura, vendredi 29 septembre 2000. Netzarim Gaza, wax sculpture.

Source: $1.60 \times 2.33 \times 0.40 \mathrm{~m}$. Collection Musée d'Art Moderne Grand Duc Jean, Luxembourg. Courtesy Pascal Convert and Galerie Eric Dupont, Paris.

Convert's series of sculptures are slow to reveal their mysteries, demanding an investment in time incongruous with the rapid consumption of the news image. As Didi-Huberman observes, "We are very far from any photograph" ("Nous sommes bien loin de tout cliché"). ${ }^{23}$ This is precisely Convert's point, as he has drawn from famously controversial images of grief and mourning from print and television. The first in the series, Pietà du Kosovo (1999-2000) (Plate 15), was inspired by a photograph taken by photographer Georges Mérillon from 1990 Veillée funèbre au Kosovo. In the immediate foreground is the body of an ethnic Albanian man, Elshani Nashim, who had been killed by Serbian police. Mérillon obtained access to an intensely private moment at the wake where the women grieve separately from the men. He is surrounded by his family and neighbours who form an arc around his body. His body is covered with a sheet, leaving only his head exposed. At the centre of the image is Nashim's mother, her head thrown back in a gesture of extreme anguish and sorrow. Mérillon's photo won the World Press Photo of the Year award in 1990, ensuring the image's iconic status in the history of photojournalism.

The second wax sculpture in the series is entitled Madone de Bentalha (2000-02) (Plate 16). Unlike the negative space created by the imprints, the sumptuous folds of the figure's robes spill out into the spectator's space. This sculpture was inspired by 
photographer Hocine Zaourar's iconic image of a crying woman Massacre à Bentalha (1997). Zaourar was covering the civil unrest in Algeria in the wake of the 1997 elections. In the small town of Bentalha, between 50 and 100 men went on the rampage for several hours, slaughtering over 400 people. Travelling there the next day, Zaourar found this woman near the hospital where the dead and injured had been taken. In her grief, she avoids the direct gaze of the camera, her eyes are averted somewhere to the right of the photographer. ${ }^{24}$ Her mouth is partly open in a cry of distress we cannot hear. Her companion attempts to comfort her, placing her hand on the woman's heart. The photograph was widely distributed, subsequently reproduced in over 700 publications worldwide and Zaourar also won the World Press Photo award in 1997.

Like its predecessors, the third in Convert's series, Mort de Mohammed Al Dura (2002-03) (Figure 11.1), was taken from news media, the video stills of Mohammed Al Dura's death on 30 September 2000. The stills depict the death of a young twelveyear-old boy, Mohammed, caught by cameraman Talal Abu Rahmeh and broadcast on French television. Trapped in the cross fi re between Palestinian and Israeli troops in the Gaza strip, he was attempting to seek cover with his father. It was moments later that Mohammad was shot and killed. The footage achieved notoriety because of the controversy surrounding its veracity. Its authenticity was immediately contested by Israel and questions remain today as to whether the child was killed by Israeli or Palestinian forces.

Something else in Convert's relief unsettles the spectator. Despite being drawn from tragedies occurring in the Muslim world, the photographs point to Christian iconography. By abstracting the press image from its original context and recasting it in another medium, wax, Convert deliberately straddles religions. Something else in Convert's relief unsettles the spectator. Despite being drawn from tragedies occurring in the Muslim world, the photographs evoke long histories of Christian iconography, especially scenes drawn from the Lamentation. By abstracting the press image from its original context and recasting it in another medium, wax, Convert self-consciously straddles religions. Convert's decision to use wax draws a comparison with the devotional practice of votive offerings. The practice of casting body parts in wax as offerings for saints or deities was particularly predominant in the Middle Ages, but as Aby Warburg has demonstrated, a practice that continued right up until the end of the eighteenth century. ${ }^{25}$ In his 1902 essay examining Quattrocento Florentine portraiture, Warburg described the tradition of making votive gifts, or effi gies, in the church of Santissima Annunziata. For Didi-Huberman, wax is a medium endowed with a labile plasticity, meaning it can be reused and recycled for multiple purposes and devotional gifts. He observes votive images, "cut across time. They are common to highly disparate civilizations. They disregard the cleavage of paganism and Christianity." 26 Convert's sculptures reinforce Warburg's central premise: images migrate through geographies, contexts, and mediums. They contain a temporal duration that exceeds the time they represent or document.

Convert acknowledges the power of the press photos was from Christian iconography of the passive martyr, encompassing images of the "Madonna," "Pietà," "Lamentation," "Deposition," and "Massacre of the Innocents." This process of cross-religious migration, however, is not the result of a simple appropriation or more problematically, a form of religious colonization, as some critics have observed. ${ }^{27}$ As Convert describes it: "What we refuse to see comes back with a vengeance, 
even if we tame it by imposing a Christian reading." ${ }^{28}$ It is worth pausing here to consider the implications of Convert's statement. His choice of the verb to tame suggests subjugation and even dilution of the power contained in the original press photos. I would like to argue the opposite: by refusing to look, the images return with fervour and energy. Again, Deleuze is helpful here. Evoking the force of the eternal return, Deleuze observes a certain "selective character" in the behaviour of the eternal return. He writes, "Only the extreme forms return-those which, large or small, are deployed within the limit and extend to the limit of their power." ${ }^{29}$ The eternal return signals not simply a return of the same, but an intensification and affi rmation. The intensifi cation in the return is something Warburg himself commented on in his discussion of emotive gestural forms. In a 1915 text he describes the infl uence of antiquity on Renaissance art that "led to an idealized style of intensified mobility." ${ }^{30}$

Convert's sculptures reinforce a central concern in Didi-Huberman's writing: images are necessarily anachronistic, containing a temporal duration that exceeds the time they represent or document. This is what Aby Warburg meant when he described the ghost-like temporality of Nachleben. Images from the past return to haunt the present. At the same time they look forward to a future that has yet to occur. In relation to Convert's works, Didi-Huberman describes this duration as a history's destiny that produces a future beyond itself:

What is a destiny? It is what history produces beyond itself: it is what directs it both towards a past, which it does not remember and a future which it does not yet know.

Mais qu'est-ce qu'un destin? C'est ce que l'histoire produit au-delà d'elle-même: c'est ce qui l'engage vers un passé dont elle ne se souvient plus et vers un futur qu'elle ne connaît pas encore. ${ }^{31}$

In Convert's sculptures, gestures of extreme grief and mourning return from the past, migrating across time, cultures, and geographies. These works collapse the historical distance that is the origin or source of Holly's melancholy. Time is no longer considered an impediment to accessing the image. Instead, the images return, intensified in their jubilant affirmation of difference.

In conclusion, what are the implications of Didi-Huberman's rereading of Aby Warburg? At odds with a melancholic formulation of history as an obstacle to accessing the art object, for Warburg, a living history survives its past. The convergence of Nachleben with the eternal return enables us to rethink the discourse of art history in terms of difference, not absence. Freud's theorization of melancholia is directed by the subject's trauma experienced by a loss of origin. The lost object is absorbed by the ego, and the ego itself becomes the source of melancholy. This process of identification, reducing the lost object to the same, is antithetical to the Deleuzian formulation of difference. In Warburg's model of Nachleben, repetition must not be understood in terms of equivalence or substitution, but on the contrary, to a transmutation and intensification. This impulse is particularly helpful for understanding the power of Convert's sculptures. Working against a melancholic reading of violent and traumatic press images, Convert leverages the redemptive power of the eternal return, reimaging the images in terms of affirmation and joy. 


\section{Notes}

1. Michael Ann Holly, The Melancholy Art (Princeton: Princeton University Press, 2013), 98.

2. Holly, Melancholy Art, xix.

3. Sigmund Freud, "Mourning and Melancholia," in The Standard Edition of the Complete Psychological Works of Sigmund Freud, Vol. 14 (London: The Hogarth Press, 1956-1974), 253.

4. Freud, "Mourning and Melancholia," 251.

5. Holly, Melancholy Art, 24.

6. Freud, "Mourning and Melancholia," 246.

7. Freud, "Mourning and Melancholia," 251.

8. See Jennifer Radden, The Nature of Melancholy: From Aristotle to Kristeva (Oxford: Oxford University Press, 2002), 12-15.

9. Jacques Derrida, "Structure, Sign and Play in the Discourse of the Human Sciences," in The Structuralist Controversy: The Languages of Criticism and the Sciences of Man, eds. Richard Macksey and Eugenio Donato (Baltimore: Johns Hopkins, 1972), 264.

10. See especially Mieke Bal, Quoting Caravaggio: Contemporary Art, Preposterous History (Chicago: University of Chicago Press, 1999); Alexander Nagel and Christopher S. Wood, Anachronic Renaissance (New York: Zone Books, 2010).

11. O. Dumoulin, "Anachronisme," in Dictionnaire des sciences historiques, ed. A. Burguière (Paris: PUF, 1986), 34.

12. Erwin Panofsky, "Introduction: The History of Art as a Humanistic Discipline," in Meaning in the Visual Arts (Harmondsworth: Penguin, 1970), 48.

13. Holly, Melancholy Art, 6.

14. Jacques Rancière, "Le concept d'anachronisme et la vérité de l'historien," l'Inactuel, no. 6 (1996). Nicole Loraux, "Éloge de l'anachronisme en histoire," Le Genre humain, no. 27 (1993).

15. The term is Loraux's. She writes, "L'anachronisme est la bête noire de l'historien." See "Éloge de l'anachronisme en histoire," 23.

16. Aby Warburg, "Italian Art and International Astrology in the Palazzo Schifanoia (1912)," in The Renewal of Pagan Antiquity: Contributions to the Cultural History of the European Renaissance, ed. Steven Lindberg (Los Angeles: Getty Research Institute for the History of Art and the Humanities, 1999), 585.

17. Aby Warburg, "Dürer and Italian Antiquity (1905)," in The Renewal of Pagan Antiquity: Contributions to the Cultural History of the European Renaissance (Los Angeles: Getty Research Institute for the History of Art and the Humanities, 1999), 558.

18. Georges Didi-Huberman, L'image survivante: histoire de l'art et temps des fantômes selon Aby Warburg, Paradoxe (Paris: Les Éditions de Minuit, 2002), 39. Didi-Huberman writes, "le temps de l'image n'est pas le temps de l'histoire."

19. Georges Didi-Huberman, "Artistic Survivial. Panofsky vs. Warburg and the Exorcism of Impure Time," Common Knowledge 9, no. 2 (2003): 273.

20. Gilles Deleuze, Nietzsche and Philosophy (New York: Bloomsbury, 2006), 8.

21. Deleuze, Nietzsche, 179.

22. Didi-Huberman, L'image survivante, 173; author's translation.

23. Georges Didi-Huberman, "Image, événement, durée," Images Re-vues Hors-série 1 (2008), http://imagesrevues.revues.org/787; author's translation.

24. For a discussion on the photojournalism of the Algerian Civil War, see Joseph McGonagle, "Dispelling the Myth of Invisibility," in The Violence of the Image: Photography and International Conflict, eds. Liam Kennedy and Caitlin Patrick (London and New York: I.B. Tauris, 2014).

25. Aby Warburg, "The Art of Portraiture and the Florentine Bourgeoisie (1902)," in The Renewal of Pagan Antiquity: Contributions to the Cultural History of the European Renaissance (Los Angeles: Getty Research Institute for the History of Art and the Humanities, 1999), 189-90.

26. Georges Didi-Huberman, "Ex-Voto: Image, Organ, Time," L’Esprit Créateur 47 no. 3 (2007): 7.

27. See, for instance, Gen Doy, Drapery: Classicism and Barbarism in Visual Culture (London and New York: I. B. Tauris, 2002), 217-18. 
28. Pascal Convert, Lamento: Pascal Convert 1998-2005 (Luxembourg: Musée d'Art Moderne Grand-Duc Jean (Mudam Luxembourg), 2007), 12.

29. Gilles Deleuze, Difference and Repetition, trans. Paul Patton (New York: Columbia University Press, 1994), 41.

30. Warburg, "The Emergence of the Antique as a Stylistic Ideal in Early Renaissance Painting (1914)," 271; emphasis mine.

31. Didi-Huberman, "Image, événement, durée," author’s translation.

\section{References}

Bal, Mieke. Quoting Caravaggio: Contemporary Art, Preposterous History. Chicago: University of Chicago Press, 1999.

Convert, Pascal. Lamento: Pascal Convert 1998-2005. Luxembourg: Musée d'Art Moderne Grand-Duc Jean (Mudam Luxembourg), 2007.

Deleuze, Gilles. Difference and Repetition. Translated by Paul Patton. New York: Columbia University Press, 1994.

Deleuze, Gilles. Nietzsche and Philosophy. Translated by Hugh Tomlinson. New York: Bloomsbury, 2006.

Derrida, Jacques. "Structure, Sign and Play in the Discourse of the Human Sciences," in The Structuralist Controversy: The Languages of Criticism and the Sciences of Man, edited by Richard Macksey and Eugenio Donato, 247-72. Baltimore: Johns Hopkins, 1972.

Didi-Huberman, Georges. "Artistic Survivial. Panofsky vs. Warburg and the Exorcism of Impure Time," Common Knowledge 9, no. 2 (2003): 273-85.

Georges, Didi-Huberman. “Ex-Voto: Image, Organ, Time,” L'Esprit Créateur 47, no. 3 (2007): 7-16.

Didi-Huberman, Georges. "Image, événement, durée," Images Re-vues Hors-série 1 (2008). http://imagesrevues.revues.org/787.

Didi-Huberman, Georges. L'image survivante: histoire de l'art et temps des fantômes selon Aby Warburg. Paradoxe. Paris: Les Éditions de Minuit, 2002.

Doy, Gen. Drapery: Classicism and Barbarism in Visual Culture. London and New York: I. B. Tauris, 2002.

Dumoulin, O. "Anachronisme," in Dictionnaire des sciences historiques, edited by A. Burguière. Paris: PUF, 1986.

Freud, Sigmund. "Mourning and Melancholia," translated by James Strachey. In The Standard Edition of the Complete Psychological Works of Sigmund Freud, Vol. 14, 243-58. London: Hogarth Press, 1956-1974.

Holly, Michael Ann. The Melancholy Art. Princeton: Princeton University Press, 2013.

Loraux, Nicole. "Éloge de l'anachronisme en histoire," Le Genre humain 27 (1993): 23-39.

McGonagle, Joseph. "Dispelling the Myth of Invisibility: Photography and the Algerian Civil War," in The Violence of the Image: Photography and International Conflict, edited by Liam Kennedy and Caitlin Patrick, 60-77. London and New York: I.B.Tauris, 2014.

Nagel, Alexander and Christopher S. Wood. Anachronic Renaissance. New York: Zone Books, 2010.

Panofsky, Erwin. "Introduction: The History of Art as a Humanistic Discipline," in Meaning in the Visual Arts, 23-50. Harmondsworth: Penguin, 1970.

Radden, Jennifer. The Nature of Melancholy: From Aristotle to Kristeva. Oxford: Oxford University Press, 2002.

Rancière, Jacques. "Le concept d'anachronisme et la vérité de l'historien,” l'Inactuel, 6 (1996): 53-68.

Warburg, Aby. "The Art of Portraiture and the Florentine Bourgeoisie (1902)," in The Renewal of Pagan Antiquity: Contributions to the Cultural History of the European Renaissance, 185-221. Los Angeles: Getty Research Institute for the History of Art and the Humanities, 1999. 
Warburg, Aby. "Dürer and Italian Antiquity (1905)," in The Renewal of Pagan Antiquity: Contributions to the Cultural History of the European Renaissance, 553-8. Los Angeles: Getty Research Institute for the History of Art and the Humanities, 1999.

Warburg, Aby. "The Emergence of the Antique as a Stylistic Ideal in Early Renaissance Painting (1914)," in The Renewal of Pagan Antiquity: Contributions to the Cultural History of the European Renaissance, 271-3. Los Angeles: Getty Research Institute for the History of Art and the Humanities, 1999.

Warburg, Aby. "Italian Art and International Astrology in the Palazzo Schifanoia (1912)," in The Renewal of Pagan Antiquity: Contributions to the Cultural History of the European Renaissance, edited by Steven Lindberg, 563-91. Los Angeles: Getty Research Institute for the History of Art and the Humanities, 1999. 